\title{
Sexuality and partnership: Aspects of theological ethics in the field of marriage, unmarried and
} homosexual couples

\author{
Ulrich H J Körtner (University of Vienna) ${ }^{1}$ \\ Research associate: Department of Dogmatics and Christian Ethics \\ University of Pretoria
}

\begin{abstract}
The attitudes towards sexuality in Western society are undergoing dramatic change. One of the main problems sexual ethics has to deal with today is the question whether the church should acknowledge unmarried long-term relationships. The debate about the acknowledgement of homosexuality as a form of human sexuality equal to heterosexuality is aiming towards the acknowledgement of the equal status of homosexual partnerships and heterosexual marriages as a final consequence. In addition to these issues the article also discusses the issue of the blessing of unmarried or homosexual couples. In light of such public blessings and their liturgical form, the article aims to discuss the question about the promise such blessings holds according to Christian ethics.
\end{abstract}

\section{ON THE TASK OF SEXUAL ETHICS}

The social changes of the past decades in the field of sexuality and gender, as well as the emergence of new life forms, confront sexual and social ethics with altogether new challenges. It is therefore necessary to clarify the general task of contemporary sexual ethics before starting any discussion concerning

\footnotetext{
${ }^{1} \mathrm{Dr}$ U H J Körtner is Professor in the Protestant Faculty of Theology, University of Vienna and Director of the Institute for Systematic Theology and the Institute for Ethics and Law in Medicine of the University of Vienna. Prof Dr Körtner is the research associate of Prof Dr D E de Villiers, Department of Systematic Theology and Christian Ethics, Faculty of Theology, University of Pretoria. This article is a reworked version of a guest lecture presented at the University of Pretoria, 30 July 2007, translated by Tobias J Körtner in English, and edited by Ettienne de Villiers
} 


\section{Sexuality and partnership}

material ethics (Keil 1966; Thielicke 1966; Ringeling 1968; Trillhaas 1970; Rendtorff 1991:5-21, 41-47, 65-71, 99-102, 117-119, 134-136; Honecker 1995:51-229).

Like all ethics the theological formation of opinions concerning questions of contemporary sexual ethics ranges within the area of conflict between the biblically testified Word of God as the basis of Christian faith and action, and the present situation of man. In principle it has to be established that the Bible, read as Holy Scripture, on the one hand ranks as a normative text, yet on the other hand it cannot be claimed as a direct source of theological ethics. The Scripture is the normalising authority, as far as it envisions the Word of God, but not in terms of a law code. The Scripture has the status of a source and has exemplary significance for the ethical formation of an opinion. However, experience and rationality also belong to the sources of the ethical formation of opinions. Theological ethics is the attempt of critically dealing with an antecedent experience of life, guided by the testimony of the Scripture, which is meant to enable the exercise of responsibility.

According to Biblical understanding, sexuality is constitutive for personhood (Gn 1:27) (Körtner 1999b:233-253). According to the second creation account, the initially lonely Adam is not an asexual but a male being destined for a personal counterpart, who does not find his equivalent among the animals, but in Eve (Gn 2:18). Extensive passages of the Old Testament revolve around sexuality, most of all around the aspect of fertility (cf Gn 1:28; 12:2). Karl Barth interprets the gender differences of human beings, who are destined for gender relationships, as well as for a relationship with God, as an indication of God's Trinity, who has to be thought of as a relationship between Father, Son and Holy Spirit (Barth 1951).

The fact that the human being in its sexual bipolarity is the image of God raises the question whether the biblical God of creation is a sexual being too. It is, however, remarkable that this is not the case, even though Yahweh is in some respects a fertility deity. Even if God's alliance with Israel can be described by the prophets with images of love, matrimony and jealousy, it differs fundamentally from the Canaanite Baal, who is clearly connoted in a sexual way, and whose cult poses a constant temptation in Old Testament Israel. Hebrew inscriptions, however, show that the Syro-Palestinian goddess Aschera (compare with Jdg 2:13; $1 \mathrm{Ki} \mathrm{11:5} \mathrm{et} \mathrm{al)} \mathrm{was} \mathrm{temporary} \mathrm{worshipped}$ as Yahweh's wife. Biblical tradition, however, fights the image of Yahweh being married to a woman. Yahweh can sometimes be compared to a mother (Is 66:13; compare Ps 131:2), yet it is questionable whether the biblical God really is an androgynous being, as is claimed by contemporary approaches of 
feminist theology (Miles 1996). In any case, in the comparison in terms of history of religions it stands out that the God of Israel has no genealogy and no sexual desires. The danger of a naive anthropomorphism is thus defied.

At the same time, this accounts for the reserve of the Biblical and Christian tradition to interpret human sexuality as a medium of a religious experience of transcendence. In terms of a psychoanalytical interpretation, sexual desire (libido) is driven by the wish to transgress separating personboundaries, social taboos and day-to-day routines. It is therefore not astonishing that sexuality is frequently understood religiously as a transcendental experience. In his critique of Sigmund Freud's psychoanalytical drive theory, Gunter Dux rightly emphasises that the gender relation enables the experience of intimacy, the integration of life's physicality in all its forms of expression, as well as the unique possibility to assure oneself of the significance of one's own being by means of the other (Dux 1994). There is, however, the almost religious hope of a kind of redemption from nothingness in the medium of the physical (Bahr 1996:270-274), which also manifests itself in today's post-religion of earthly love (Beck \& BeckGernsheim 1990). At the same time, there is the danger of separating sexuality from human personality, as well as eroticism and love, with the consequence of an over-sexualisation of all areas of life. That estranged sexuality can be a form of sin, even though the one-sidedness with which sexuality and $\sin$ have been associated has to be theologically rejected, remains a moment of truth of the traditional Christian doctrine of sins.

An anthropology, representing a cognitive and body-adverse understanding of man as a rational being, must perceive the urge of sexuality as a threat. Such tendencies also exist in the history of Christianity. Contemporary theology rightly stresses the physicality or corporeality ("Leiblichkeit" [Maurice Merleau-Ponty]) of rationality. Even in its perversions human sexuality remains a human form of expression. It does not become animal, but inhuman.

Part of the basic conditions of modern ethics, and consequently also theological-ethical reflection, is firstly the distinction between legality and morality, and secondly the difference between privacy and publicity. Both distinctions have to be accommodated in the reflection on the formation of opinions concerning questions of sexual ethics. The problems of sexual ethics lie at the interface of individual, personal and social ethics. Apart from that, moral and juridical aspects overlap in the field of sexual ethics. Several of the ethical conflicts result exactly from the overlap of the aforementioned levels.

The formation of opinions in sexual ethics furthermore has an ecclesiological dimension. Ecclesiastical comments on questions of social 


\section{Sexuality and partnership}

ethics generally need to consider the self-image that governs the church as a denomination and a social institution in its life and actions. As is the case with all ethical decisions, ecclesiastical comments on questions of sexual ethics are also about the church's position in relation to the rest of society (Ringeling 1994:163-167; Rendtorff 1994:190-202). The question, consequently, is whether the church sees itself as a people's church or a minority church, whether it - as a church for others - wants to be church for everyone or primarily for fringe groups and whether it perceives itself as part of society or as the demonstrative counterpart of society. The ecumenical dimension also has to be taken into consideration (i.e., in view of the ecclesiastical status of married couples from different religious denominations and the theological basis of so-called ecumenical weddings).

The attitudes regarding sexuality in our society are subject to a dramatic change. The changes in the field of sexuality, matrimony and family can only be theologically reflected in an adequate way if they are not immediately abstractly examined in terms of ethical viewpoints, but if they are analysed socio-historically first (Schelsky 1977; Beck \& Beck-Gernsheim 1990). At the same time, one needs to consider the historical conditionality and narrowness of the traditional Christian sexual morality and doctrines on the institutions of matrimony, family, work and the state (Ratschow et al 1982). Otherwise, historically contingent realities are confused with the unconditionality of the Word of God and demonised through its sacralisation (Schellong 1983). For the ecumenical perspective of theological ethics, the comparison of cultures is relevant in this respect as well (Hastings 1973; Völger \& Von Welck 1985).

One of the main problems of contemporary sexual ethics is the question whether the church should acknowledge unmarried long-term relationships and under which circumstances it should do so (Ehe und nichteheliche Lebensgemeinschaften 1985; cf Ringeling 1993:298-316). The debate about the acknowledgement of homosexuality as a form of human sexuality equal to heterosexuality aims at the equal status of homosexual partnerships and heterosexual marriages as a final consequence. It, of course, also has to be taken into consideration that not every human being, regardless of whether he or she is hetero- or homosexual, actually wants to form a fixed, long-term partnership. This set of problems needs to be treated separately and has to be distinguished from the question on how nonmatrimonial long-term relationships respond to matrimony as a legal institution and to the ethical norm of lifelong community, which governs the ecclesiastical notion of matrimony. 
With regard to the depicted complex of problems, it is necessary to critically reconsider the common ecclesiastical notion of heterosexual monogamy as the only acceptable form of relationships. It is not a question of challenging the particular status of matrimony and family, but it is rather a matter of winning a new understanding of matrimony in the context of the world we live in ("Lebenswelt"). ${ }^{2}$ This is only possible if the facticity of the form of matrimony that historically evolved in our culture area, is not confused with its validity, and if the shape of the civic matrimony, conditioned by history, is not rashly derived from Biblical tradition or read into it for the purpose of its theological legitimisation.

Especially a theology of orders, which declares social structures and institutions to be natural orders, as well as orders of creation, in an unhistorical way, and which is subject to the false naturalistic conclusion that existing social structures are God-given prescriptive orders, proves to be aporetic. Old Testament creation accounts do not only examine fertility as a blessing of God, but also sexuality in its wider sense, namely as an elementary force of mutual attraction between man and woman, which is granted with and rooted in the creation of human beings (Gn 2:24). The erotic lyricism of the Song of Solomon corresponds to this. It has to be kept in mind, however, that the mentioned texts do not speak of the familiar, legally developed institution of matrimony. The metaphysical assumption of eternal, inalterable social orders has to be criticised not only philosophically with Paul Tillich as „myth of origin” but also theologically. One can object to the approach of a theology of creational orders that it does not include any criteria that can help us to distinguish which social orders are divine instructions and which ones are not. Furthermore, such an assumption operates with an unspecified notion of nature, in that it does not take into consideration that nature always appears in society culturally embedded and cannot in abstract terms be called 'the other' in contrast to society. The contrast between alleged natural orders and social orders therefore is relative. Social orders are also extremely changeable. And finally, the nationalist, racist and power-political abuse of the notion of orders in the past has to be mentioned from an ideological critical perspective.

At the same time, ethics - including sexual ethics - that exclusively constricts itself to the approach of situation ethics, is deficient. The social dimension of human life demands structures and institutions that are versatile and, if necessary, can be replaced by other institutions, yet are generally indispensable. Wherever antiquated institutions disappear, functional

\footnotetext{
${ }^{2}$ For the position of the evangelical church(es) in Germany see: Kirchenkanzlei der EKD 1981; Kirchenamt der EKD 1988.
} 


\section{Sexuality and partnership}

equivalents emerge. The use of such functions will be analysed in the following, by means of an analysis of the interrelation between the natality and sociality of human beings. The themes of contemporary sexual ethics do not open up via a reflection on sexuality per se, but via reflection on the anthropological fact that a human being essentially is a being characterised by being born. Hannah Arendt calls this the notion of natality ("Geburtlichkeit").

\section{NATALITY AND SEXUALITY}

All ethical reflections, even the socio-ethical and sexual ethical, must reflect the anthropological polarity of freedom and fate (Tillich 1977:214ff). All ethical acting is based on natural conditions, which are not arbitrary, yet nonetheless not morally normative per se, but rather provoke an ethically grounded statement. The "natural non-arbitrariness of normative reason" (Wilhelm Korff, Franz Böckle) constitutionally belongs to these requirements, as well as our finiteness, which consists of our mortality and our natality in equal measure. With our natality, however, the biological difference of the sexes and the natural non-arbitrariness of the own biological sex and the possibility of propagation of life are given.

Together with the natality of a human being his or her sociality is given. We can also say that childhood and parenthood are "the social universal" (Honecker 1995:153). No human being exists without biological parents, and no human can develop into an independently viable creature without somebody else's care. Our existence is not only the result of conception, pregnancy and birth, but also of care and upbringing during infancy and childhood. Every human being is, at the beginning of his or her life, a completely dependent being. The state of needing help can also reoccur later in life, which for many people is the case at the end of life. Human sociality, given by natality, is the succession of generations exceeding its beginning and end respectively. In this respect one can say that the family is the basic structure of human sociality.

On the one hand, a human being's family and sexuality belong together, but they have to be distinguished on the other hand. Together with natality, sexuality belongs constitutively to the personal identity of every human being. It does not limit itself to the biological function of fertility, but it is also a dimension of a holistic concept of being a person in every aspect. Sexuality is a form of language; a medium of personal communication. It is not simply innate, but it is acquired because of existing dispositions and thus is a part of the person, who is formed in interpersonal communication (Kentler 1983, 1988). Therefore, sexuality has its own right and value, regardless of its social function in being a person, although at the same time any sexual 
behaviour has its place in social and cultural contexts. Together with the dignity of the person, a person's sexual orientation must also generally be respected. Therefore, every human being has to be granted a way of living according to his or her sexual orientation. This, of course, requires the responsible handling of one's own sexuality and the sexuality of fellow human beings. As far as the personal conduct of life is a task of ethics, it includes the integration of one's own sexuality in relation to oneself (level of individual ethics), as well as in relation to other humans (level of personal ethics). Not the human sexual orientation as such, which is formed in a complicated way during the ontogenesis, but the responsible treatment of it is the task of forming sexual ethical opinions. This holds equally true for heterosexual, homosexual and bisexual people. An elementary criterion for a responsible attitude towards one's own sexuality is, according to Christian understanding, in any case the double commandment of love (Mt 22:37-39), which includes respect for the other's personal dignity.

As far as a human being, according to his or her "nature“, is a personal and moral being, that is, a being designed for personal responsibility in everything he or she does, natality, sexuality and structures resembling a family never appear per se, but always only as culturally formed and morally reflected. Matrimony therefore is not a natural condition but a social institution with a legal value. Institutions are long-term functionally governed ways of living and functionally determinable social systems respectively. Matrimony and family are the ethical way of life in which natality and structures resembling a family are constructed culturally. It follows that matrimony is no natural condition, but that institution that can be found in every society, at the interface of the difference between sexes and parenthood. It is the social place at which the relationship between man and woman becomes durably viable in intersection with the relationship between parents and children. In detail the cultural form of matrimony and family can vary considerably. Both living together as man and woman and living together as adults and children are subject to considerable changes nowadays. In the meantime, there are quite diverse family patterns, ranging from the single-parent-family and the "continuation family" of re-married divorced people, up to complicated forms of the "patchwork family" (Lüscher, Schultheis \& Wehrspaun 1988; Ley \& Borer 1992; Bernstein 1990; Rauchfleisch 1997; Hötzel 1998). Yet no society is conceivable in which these forms do not occur in some form, or functional equivalents are produced, which are derived from previous forms of matrimony and family. 


\section{Sexuality and partnership}

\section{FAMILY, MATRIMONY AND NON-MATRIMONIAL PARTNERSHIPS (FOR LIFE)}

The distinctiveness of matrimony compared to other possible forms of human beings living together results from the overlap of living together as man and woman and living together as parents and children. In this respect matrimony does not end the durable partnership of man and woman as such, but rather includes the possibility of parenthood in principle, affirmed by the spouses. For the mere community of man and woman other forms of a partnership for life would be possible (Landwehr 1978). The meaning, or rather the societal function, of the social institution of matrimony can neither be sufficiently specified through the phenomenon of love, nor through the phenomenon of sexuality. Love and sexuality are necessary, yet by no means sufficient conditions for forming and maintaining a marriage. That is why all attempts to specify the meaning of matrimony under modern societal conditions by a romantic notion of love fail. Such attempts not only misconceive matrimony's social function, but also lead to an emotional, in terms of matrimony often destructive, demand by marriage partners.

Protestant social ethics of the last decades, however, has contrasted the traditional doctrine of matrimonial purposes, which especially includes the propagation of life, with the thesis of matrimony as an end in itself (Wannenwetsch 1993). This thesis accounts for developments in the fields of contraception and family planning, which enable human sexuality to be an end in itself. It is also based on the Biblical tradition, which speaks of man and woman being united in a love relationship as a new unity, the meaning of which is not primarily reproduction, but partnership and mutual care (compare Gen 2:18, 24). ${ }^{3}$

This aspect of matrimony has increasingly become more significant in modern society. It helps to personal subjectivity and the construction of identity in a functionally differentiated society in which the individual is split into a number of social roles that are increasingly difficult to integrate into a coherent biography and identity. Yet the social function of matrimony does not end with this. The societal interest in institutionalising and privileging this specific form of a heterosexual partnership is rather rooted in its openness to progeny. The one-sided thesis of matrimony as an end in itself therefore has to be corrected to the effect that the openness to the propagation of life belongs to this specific form of a heterosexual partnership. In contrast to the common doctrine of founding a family as the purpose of matrimony, one

\footnotetext{
${ }^{3}$ For the theological interpretation of matrimony in the German-language discussion , see Bayer (1988); Bovet (1978); Gaßmann (1979) and Thilo (1978).
} 
should rather speak of the correlation of matrimony and family, in order to account for the aspect of self-valence. It follows that matrimony also has its meaning and particular dignity if it remains childless.

Matrimony and family are, not only socio-scientific-empirically, but also theologically, not to be specified as the only conceivable and acceptable form of man and woman, as well as adults and children, living together, yet they are to be seen as its exemplary case. As regards the aspect of the overlap of sexuality and the succession of generations, matrimony and family have the function of socially guiding principles. The guiding principle status of matrimony is rooted in the fact that it is based on voluntariness, reciprocity and equality, that is, it is based on affection and love, which involve the partners' entire lives and not only parts of them. Marriage is celebrated as being binding and meant to last for an indefinite duration, ${ }^{4}$ that is, it is based on faithfulness and offers reliability in all circumstances, even in times of crisis and conflicts. It enables the interpersonal integration of sexuality into the shared way of living, in order to let it enrich life on the one hand and on the other hand be saved from destruction. Finally, it creates an environment for children, in which they are welcome and can grow up securely.

From a Christian point of view the social institution of matrimony can be valued as an excellent way in which man and woman living together comply with God's will. Both a creation order theological and a commandment theological rationale are theologically insufficient. The last mentioned rationale is, for example, found in the memorandum of the Evangelical Church in Germany (EKD) on matrimony and family, which argues: „The answer of the protestant church to the question ,Why marry?' arises in a mandatory way from the preached and believed Biblical texts on matrimony, especially from the words of Jesus Christ, the master of the church, who refers to the creation account from biblical prehistory" (Kirchenamt der EKD 1998:28). In other words, Christ's ban on divorce in Mark 10:9 suggests a dictate of matrimony. This argumentation is, however, logically inadequate, because from the ban of divorce it does not logically follow that man and woman can only live together as a married couple.

A more differentiated approach to the Biblical material shows that matrimony in the bible is not seen directly but indirectly as a human possibility of conducting a life that is approved and intended by God, without demanding a particular, culturally induced form of matrimony (Ringeling 1966). Old Testament creation accounts do not only examine sexuality in its narrow meaning of reproductive instinct and fertility as a blessing of God (Gn 1:28), but they also examine sexuality in its wider meaning, namely as an

\footnotetext{
${ }^{4}$ The German word "Ehe" is related to the word "Ewigkeit" and means "long duration".
} 


\section{Sexuality and partnership}

elementary force of mutual attraction of man and woman, which is granted with and rooted in human creation (Gn 2:24). It has to be kept in mind, however, that the mentioned texts do not speak of the legally developed institution of matrimony that is familiar to us, and that Genesis 2:24 not even primarily means reproduction (Von Rad 1976:59; Westermann 1976:318), but the life defining and life changing power of love (Compare Can 8:6-7), the state of being attracted to a human being and devotedness, which can become more intense in a long-term partnership. In no way does Genesis 2:4b-24 provides aetiology of matrimony and family. It rather provides aetiology of the push of the sexes towards one other. Von Rad (1976:60) explains that the Biblical story in Genesis 2 is not about legal conventions but a natural force. The sociological distinction between biological sex (sex) and the socio-cultural classification of sexual affiliation and sexuality (gender) offers a corrective to essentialist, natural law, or order theological notions of human sexuality, which attribute certain gender roles, as well as historically contingent social forms (matrimony, family) - also reflected in Biblical texts directly to a divine decree.

It rather has to be emphasised that the institution of matrimony (regardless of mono- or polygamy), as it occurs in the Old Testament, this drive of the sexes towards each other, is not the only element, and often not even the crucial element; in general, familial, social, and economic elements are decisive when it comes to matrimony.

(Westermann 1976:317-318)

Nevertheless, one can theologically argue that not only the sex drive and personal love confirm God's will, according to Biblical tradition, but indirectly also the institutionalisation of man and woman living together, as far as the forbiddance of adultery (Ex 2:14 and Mt 5:27-32), and the ban on divorce (Mk $10: 7-12 ; 1$ Cor 7:13 \& 6:6), inculcated by Jesus with reference to Genesis $2: 24$, require the legal status of a formally celebrated marriage and deem the latter worthy of protection.

In the New Testament, however, sexuality and matrimony, as well as the family are subject to the eschatological restriction (1 Cor 7 and Mk 12:1824) that they are a form of the decaying world. This practically means that for Christians also singleness and celibacy are possible forms of living and that they are of the same value as matrimony. In accordance with the distinction between saving acts of God and blessings of God in the bible, introduced by Claus Westermann, it must be said that matrimony and family belong to the 
sphere of God's blessing acts, yet not to the sphere of salvation through God (Frettlöh 1998; Greiner 1998; Obermann 1998; Körtner 1999a and Westermann 1981). Therefore they are - to quote Luther - a "worldly thing" and they have no sacramental character, in contrast to Roman Catholic doctrine, which counts matrimony among the sacraments.

In their entirety, the aforementioned elements of human life are only viable in matrimony and family. Yet the churches should acknowledge that important elements of matrimony and family can also be ethically realised in other forms of living together. Judged socio-ethically, also partnerships that resemble a marriage deserve recognition, respect and protection, as far as they are ethically justified in a way that bears analogy to matrimony and are lived in a responsible way. The will to live together permanently, holistic personal devotion and faithfulness have to be assumed. A partnership that has been formed with internal reservations or a relationship with changing sex partners cannot be said to be a partnership resembling a marriage.

\section{HOMOSEXUAL LIFESTYLE}

The theological evaluation of homosexuality in general, of homosexual partnerships and blessing services for homosexual couples is highly controversial. While the Lutheran Church and the Reformed churches in the Netherlands, as well as the Reformed Church in Austria, support the blessing of same-sex couples, other protestant churches still reject public worships for homosexual couples. The Council of the Evangelical Church in Germany published its study "Living with Tensions" in 1996 (Mit Spannungen leben 1996), which deems a blessing of homosexual couples at best acceptable in the field of individual pastoral care. The church public is deeply divided over this question. The theological discussion is, amongst other reasons, so complicated, because the problem cannot be dealt with without the question of the contemporary understanding of matrimony, its correlation with the family and with non-matrimonial heterosexual long-term partnerships (Lienemann 1998; Wannenwetsch 1994).

According to Christian understanding, matrimony, geared to the family, is the guiding principle of living together on the social and the personal level. It is, however, only a suitable form of living for heterosexual oriented people, possibly also for bisexual people, in case they can resolve not to live out their homosexual tendencies. For people who are clearly and invariable homosexual, it is obvious that they cannot form a heterosexual relationship (Morgenthaler 1987; Rauchfleisch 1994). The word of the New Testament, according to which everybody is free to celebrate marriage (Mt 18:11), is in turn also valid for homosexually inclined people. Like for heterosexual people, 


\section{Sexuality and partnership}

it also implies for them that it is their moral duty to integrate their sexuality responsibly and in the spirit of love into their existence as persons. Traditional ecclesiastical sexual ethics has argued that for homosexual people the alternative to the, for them impossible, marriage was sexual abstinence. It did not want to acknowledge that there also could be a form of homosexual living in which these people experience the happiness of a durable relationship and - just like heterosexual people - live their sexuality in a responsible way.

Theology and the church, in my opinion, ought to acknowledge the possibility that homosexual people form a durable same-sex partnership for life in an ethically responsible and thus, from the perspective of Christian faith, approvable manner. Such a responsible homosexual partnership follows the criteria of heterosexual monogamy and analogically is defined by voluntariness, completeness, obligation, perpetuity, and partnership (Bovet 1965; Pratscher 1994; Wiedemann 1989; Kreß \& Müller 1998:204). It then is a, compared with heterosexual monogamy, independent form of living, which is still based on the guiding principle of matrimony. Realistically speaking, one will have to act on the assumption that even if such partnerships for life are legally acknowledged and are no longer socially discriminated against, only a minority of homosexuals will adopt a way of living along the lines of matrimony.

Hence, if the possibility of homosexual relationships is theologically and ecclesiastically acknowledged, this does not mean that the social guiding principle of matrimony will be abandoned (Koch 1998). Examined more closely, the function of matrimony and family as guiding principles is not affected at all by a revaluation of homosexuality, but it is, on the contrary, even strengthened by an acknowledgement of homosexual relationships. This, however, is only valid as far as the acknowledgement of homosexual partnerships for life is based on the acknowledgement of the human dignity of the person, irrespective of one's sexual orientation, and on society's obligation to protect the respect for minorities and not on the assumption that homosexuality as such is a hyper-individual common property, that shares the same overall social interest as heterosexuality. As for its social function, matrimony and family are not on the same level as homosexual relationships. Nevertheless, such relationships can acquire a social function that is socially desirable and therefore also worth supporting. In analogy to matrimony, a durable partnership for life can help to stabilise the identity and personality of homosexual people and become the place of reciprocal help in all situations in life.

It follows from the previous observations that the institution of matrimony shall be reserved for heterosexual couples and that it deserves 
special public protection and ecclesiastical appreciation, because of its correlation with starting a family. Nonetheless, other forms of living together are to be acknowledged and considered legally, provided that they correspond to the criteria mentioned before. One therefore also has to think about the possibilities of how to make a homosexual long-term partnership public and legally acknowledged and how it can benefit in terms of, for instance, Tenant Law and the law of succession. This socio-ethical question should have precedence over the, at present, severely discussed question of the theological admissibility of blessing services for non-matrimonial and homosexual partnerships. Socio- and sexual-ethical questions cannot be solved in the domain of liturgics. The liturgical consequences of forming socioethical opinions, however, need to be discussed too.

\section{ON THE QUESTION OF BLESSING UNMARRIED OR HOMOSEXUAL COUPLES}

For liturgical acts of the church it follows that they have to express and allow for the special status and protection requirements of matrimony and family. This happens by means of the church wedding where not two single people are given God's blessing for their further lives, but a couple, forming a hyperindividual unity that is bindingly expressed through civil marriage, as well as the marriage avowal in a church service. The couple who has a church wedding also does not ask for God's blessing in an indefinite way, but concretely for the joint effort to live their relationship within the institutional scope and to develop it, relying upon God. This request is ecclesiastically approved of by the public church service and acknowledged before God. Marriage differs from other blessing gestures through this.

This does not eliminate the possibility of different blessings for couples, heterosexual and homosexual ones alike, besides the church wedding. Basically, the meaning of a blessing is that it is an individual promise expressing God's preservation of Creation. The blessed ones can deem themselves included in God's acts of preserving his Creation, that is, in the allembracing blessing of God, which rests on his Creation, despite the latter's brokenness due to the fall of man. Standing under God's blessing means that one's own conduct of life does not only serve the blessed one, but that it is beneficial for life in general. The series of church ceremonies in the Protestant church is certainly expandable.

Church ceremonies in analogy to the church wedding, that is, church services of a public nature, can, according to Protestant understanding, only be theologically justified if they offer a reasonable occasion for public annunciation in accordance with the Gospel. Theologically, it is very 


\section{Sexuality and partnership}

problematic that the discussion about public acts of blessing for homosexual couples so far has disregarded the aspect of preaching the Word of God and has concentrated exclusively on the act of blessing. ${ }^{5}$ Before public blessings and their liturgical shape are discussed, the question has first to be clarified, which promise in accordance with the Gospel preached in the sermon such a blessing entails. In my opinion, it follows from the previous observations that not only matrimony possesses a Biblical promise, but that partnerships for life in analogy to matrimony can partake in this blessing too. What has been said of matrimony as an end in itself also, under certain conditions, applies to other partnerships. Since, according to Biblical testimony, it is not good that man should be alone (Gn 2:18), God's blessing can also rest on a non-matrimonial, that is, on a homosexual partnership, so that it becomes a blessing, not only for the persons concerned, but also for their environment. It then needs to be testified to them that a Christian conduct of life is not only under the promise of the divine blessing, but that it is also always in need of forgiveness, yet that it can trust in the encouragement of the Gospel, from which arises the power of a new beginning. Public blessing services for homosexual couples therefore, in my opinion, ought to be generally endorsed, because, under the mentioned conditions, there are good reasons for public annunciation in accordance with the Gospel, which finds visible expression in the blessing.

In my opinion, however, a crucial criterion for supporting a public act of blessing in individual cases is whether it is really a matter of a partnership for life, that is, a holistic and indefinitely formed relationship, which is not only made binding by means of a public promise, but also by voluntarily entering into legal commitments concerning mutual lifelong care. Otherwise, the actions of the church would become contradictory in terms of its appreciation of lifelong matrimony. One can expect from a couple not united by marriage, who wants to be blessed, that they convincingly clarify the legal arrangements made, thus showing their will to permanently live together.

The canonical questions that are in need of clarification here, as well as the question regarding the possible form of a liturgical order, cannot be further discussed here. To me, their clarification seems to be an indispensable requirement for establishing public blessing services as a new ecclesiastical practice. Furthermore, the ecumenical dimension of the decision of single churches has to be considered. Blessings usually are a matter of the discretionary authority of church officials. ${ }^{6}$ Homosexual couples thus already have the opportunity of a private act of blessing. Nonetheless, the suggestion

\footnotetext{
${ }^{5}$ The argument that I develop, differs e.g. from that of the Theological Commission of the Evangelical Church in Rhineland. Compare Sexualität und Lebensformen 1996. For criticism of this report see the opinion of several professors of the Faculty of Protestant Theology, University of Bonn (Stellungnahme 1996).

${ }^{6}$ For different blessing formulas from the European context, see Bürger (1996).
} 
in the EKD's statement "Living with Tensions" that the blessing of homosexual couples should be permitted exclusively in the sphere of privacy and individual pastoral care, is not convincing, as can be seen from the previous arguments. Such a proposal is, from a reformation point of view, extremely problematic, because it would compromise the public nature of blessings (Kreß 1996; Kreß \& Müller 1998:208-209). It has always been a concern of the Reformation to avoid a separation of blessing acts from the church service and to emphasise the connectedness of church service and everyday life through the blessing in church service. This ought to be valid for homosexual relationships, too, if they have the character of a union akin to matrimony and if the persons involved express their will to live their relationship in responsibility before God and in the Christian faith in God's grace and mercy.

\section{Works consulted}

Bahr, H E 1996. Grenzenlose Liebessehnsucht - unterentwickelte Fähigkeiten. Theologisches geschenkt: Festschrift für Manfred Josuttis. Bovenden: Foedus.

Barth, K 1951. Die Kirchliche Dogmatik, Bd. III/4. Zürich: TVZ.

Bayer, O (ed) 1988. Ehe. Zeit zur Antwort. Neukirchen-Vluyn: Neukirchener Verlag.

Beck, U \& Beck-Gernsheim, E 1990. Das ganz normale Chaos der Liebe. Frankfurt: Suhrkamp.

Bernstein, A C 1990. Die Patchworkfamilie: Wenn Väter oder Mütter in neuen Ehen weitere Kinder bekommen. Zürich: Kreuz.

Bovet, Th (ed) 1965. Probleme der Homophilie in medizinischer, theologischer und juristischer Sicht. Bern: Haupt/Tübingen: Katzmann

Bovet, Th 1978. Die Ehe: Ein Handbuch für Eheleute. Tübingen: Katzmann.

Bürger, P 1996. Da war unser Mund voll Lachen: Befreiung für die Kirche und für Christen, die das gleiche Geschlecht lieben. Düsseldorf: Eigenverlag des Verfassers.

Dux, G 1994. Geschlecht und Gesellschaft: Warum wir lieben: Die romantische Liebe nach dem Verlust der Welt. Frankfurt: Suhrkamp.

Ehe und nichteheliche Lebensgemeinschaften. Positionen und Überlegungen aus der Evangelischen Kirche in Deutschland 1995. Hannover.

Frettlöh, M 1998. Theologie des Segens: Biblische und dogmatische Wahrnehmungen. Gütersloh: Gütersloher Verlagshaus.

Gaßmann G (ed) 1979. Ehe - Institution im Wandel: Zum evangelischen Eheverständnis heute. Hamburg: Lutherisches Verlagshaus.

Greiner, D 1998. Segen und SeGene: Eine systematisch-theologische Grundlegung. Stuttgart: Kohlhammer.

Hastings, A 1973. Christian marriage in Africa: Being a report commissioned by the archbishops of Cape Town, Central Africa, Kenya, Tanzania and Uganda. London: SPCK.

Honecker, M 1995. Grundriß der Sozialethik. Berlin: De Gruyter.

Hötzel, W 1998. Beitrag zur soziologischen Beschreibung der Wirklichkeit von Ehe und Familie, in: Kirchenamt der EKD 1998:97-112. 


\section{Sexuality and partnership}

Keil, S 1966. Sexualität. Stuttgart: Kreuz.

Kentler, H (ed) 1983. Die Menschlichkeit der Sexualität. München: Kaiser.

Kentler, H (ed) 1988. Sexualwesen Mensch: Texte zur Erforschung der Sexualität. München: Piper.

Kirchenamt der EKD 1998. Gottes Gabe und persönliche Verantwortung: Zur ethischen Orientierung für das Zusammenleben in Ehe und Familie. Eine Stellungnahme der Kammer der EKD für Ehe und Familie. Gütersloh: Gütersloher Verlagshaus.

Kirchenkanzlei der EKD 1981. Die Denkschriften der Evangelischen Kirche in Deutschland: Ehe, Familie, Sexualität, Jugend. Gütersloh: Gütersloher Verlagshaus.

Koch, $T$ 1998. Ethische Überlegungen zu den Lebensgemeinschaften von Familie und Ehe, in Kirchenamt der EKD 1998:113-124.

Körtner, U 1999a. Die Bedeutung des Segens: Systematisch-theologische Überlegungen zu Segensbegriff und Segenspraxis im Christentum. Amt und Gemeinde 50, 171-184.

Körtner, U 1999b. Evangelische Sozialethik: Grundlagen und Themenfelder. Göttingen: Vandenhoeck \& Ruprecht.

Körtner, U 2004a. s v Sexualität II: Theologisch und anthropologisch. RGG, 1247128.

Körtner, U 2004b. s v Sexualität IV: Ethisch. RGG, 1250-1253.

Kreß, H 1996. Im Prinzip Ja und Nein: Die EKD-Schrift zur Homosexualität hat keine klare Linie. EK 29, 292-293.

Kreß, H \& Müller, W E 1998. Verantwortungsethik heute: Grundlagen und Konkretionen einer Ethik der Person. Stuttgart: Kohlhammer.

Landwehr, G (ed) 1978. Die nichteheliche Lebensgemeinschaft. Göttingen: Vandenhoeck \& Ruprecht.

Ley, K \& Borer, C 1992. Und sie paaren sich wieder: Über Fortsetzungsfamilien. Tübingen: Ed. Diskord.

Lienemann, W 1998. Churches and homosexuality: An overview of recent official church statements on sexual orientation. ER 50, 7-21.

Lüscher, K, Schultheis, F \& Wehrspaun, M (eds) 1988. Die "postmoderne" Familie: Familiale Strategien und Familienpolitik in einer Übergangszeit. Konstanz: Universitätsverlag Konstanz.

Marquardt, F W, Schellong, D \& Weinrich, M (eds). Einwürfe, 1. München: Kaiser.

Miles, J 1996. Gott - eine Biographie. München: Hanser.

Mit Spannungen leben. Eine Orientierung des Rates der EKD zum Thema Homosexualität und Kirche 1996. Hannover.

Morgenthaler, F 1987. Homosexualität, Heterosexualität, Perversion. Frankfurt: Qumran.

Obermann, A 1998. An Gottes Segen ist alles gelegen: Eine Untersuchung zum Segen im Neuen Testament. Neukirchen-Vluyn: Neukirchener Verlag.

Pratscher, W 1994. Homosexualität in der Bibel. Amt und Gemeinde 45, $13-22$.

Ratschow, C H et al 1982. s v Ehe/Eherecht/Ehescheidung I-IX. TRE 9, 308-362. Berlin: De Gruyter.

Rauchfleisch, U 1994. Schwule, Lesben, Bisexuelle: Lebensweisen, Vorurteile, Einsichten. Göttingen: Vandenhoeck \& Ruprecht. 
Rauchfleisch, U 1997. Alternative Familienformen: Eineltern, gleichgeschlechtliche Paare, Hausmänner. Göttingen: Vandenhoeck \& Ruprecht.

Rendtorff, T 1991. Ethik. Stuttgart: Kohlhammer.

Rendtorff, T 1994. Selbstbestimmung und Institution: Ethisch-theologische Implikationen der Kontroverse um "Homosexualität und Pfarrerberuf". ZEE 38, 190-202.

Ringeling, H 1966. Die biblische Begründung der Monogamie. ZEE 10, 81-102.

Ringeling, H 1968. Theologie und Sexualität. Gütersloh: Gütersloher Verlagshaus.

Ringeling, H 1993. Ethische Strukturprobleme der Geschlechter: Die nichtehelichen Lebensgemeinschaften: das Problem alternativer Wege zur Verbindlichkeit. Handbuch der Christlichen Ethik, 298-316. Gütersloh: Gütersloher Verlagshaus.

Ringeling, H 1994. Homosexualität als Frage kirchlichen Handelns. ZEE 38, 163-167. Schelsky, H 1977. Soziologie der Sexualität. Hamburg: Rowohlt.

Sexualität und Lebensformen sowie Trauung und SeGenung. Vorlage des Ständigen Ausschusses der EKR an die Landessynode 1996. Düsseldorf.

Stellungnahme von Mitgliedern des Professoren-Kollegiums der Ev.-Theol. Fakultät der Universität Bonn zum Diskussionspapier "Sexualität und Lebensformen" sowie "Trauung und Segnung" 1996. Bonn

Thielicke, H 1966. Sex: Ethik der Geschlechtlichkeit. Tübingen: Mohr Siebeck.

Thilo, H-J 1978. Ehe ohne Norm? Eine evangelische Eheethik in Theorie und Praxis. Göttingen: Vandenhoeck \& Ruprecht.

Tillich, P 1977. Systematische Theologie. Stuttgart: Evangelisches Verlagswerk.

Trillhaas, W 1970. Sexualethik. Göttingen: Vandenhoeck \& Ruprecht.

Von Rad, G 1976. Das erste Buch Mose: Genesis. Göttingen: Vandenhoeck \& Ruprecht.

Völger, G \& Von Welck, K (eds) 1985. Die Braut. Geliebt, verkauft, getauscht, geraubt: Zur Rolle der Frau im Kulturvergleich. Köln: Rautenstrauch-JoestMuseum für Völkerkunde.

Wannenwetsch, B 1993. Die Freiheit der Ehe: Das Zusammenleben von Frau und Mann in der Wahrnehmung evangelischer Ethik. Neukirchen-Vluyn: Neukirchener Verlag.

Wannenwetsch, B 1994. Das "Natürliche" und die "Moral": Zur neueren Diskussion um die Homosexualität in der Kirche. ZEE 38, 168-189.

Westermann, C 1976. Genesis 1-11. Neukirchen-Vluyn: Neukirchener Verlag.

Westermann, C 1981. Der Segen in der Bibel und im Handeln der Kirche. Gütersloh: Gütersloher Verlagshaus.

Wiedemann, H. G 1989. Homosexuelle Liebe: Für eine Neuorientierung in der christlichen Ethik. Stuttgart: Kreuz. 